\title{
The Exorcist in Istanbul: Processes of Transcultural Appropriation Within Turkish Popular Cinema
}

\author{
Iain Robert Smith, University of Nottingham
}

\begin{abstract}
Rather than the manufactured clash of civilisations, we need to concentrate on the slow working together of cultures that overlap, borrow from each other and live together in far more interesting ways than any abridged or inauthentic mode of understanding can allow. (Said 2003: xxii)
\end{abstract}

In the recent documentary Crossing the Bridge: The Sound of Istanbul (dir. Fatik Akin 2005), the record label bosses Ahmet Uluğ and Cem Yegül comment on the interstitial status of Istanbul:

Cem Yegül: $\quad$ Istanbul is Asia and Europe. It's East and it's West.

Ahmet Uluğ: But actually that's an advantage. We try to be European, but at the same time we're open to the East. That's a part of us too. We're open to both sides.

The film goes on to illustrate this thesis with a focus on Istanbul's varied musical culture, which ranges from traditional Arabesque singers such as Orhan Gencebay through to contemporary acts, such as the rapper Ceza and the neo-psychedelic rock group Baba Zula. Exploring the ways in which Turkish musicians have borrowed and adapted elements of musical traditions as diverse as hip-hop, fusion and post-rock, Crossing the Bridge lays emphasis on the idea of Istanbul as a 'bridge' between Europe and Asia both geographically and culturally.

Indeed, these processes of borrowing and adaptation are not simply a contemporary phenomenon. Transcultural appropriation ${ }^{1}$ has a long history within Turkish popular

\footnotetext{
${ }^{1}$ I purposefully use the term 'transcultural appropriation' as this is a study of appropriation 'across' national and cultural boundaries. In previous decades, a study of this kind may well have used the term 'intercultural' to describe such relationships, yet I have purposefully chosen 'trans' (from the Latin
} 
culture, ranging from the literary borrowings of the Edebiyyât-ı Cedîde (New Literature) movement in the early $20^{\text {th }}$ century through to the more recent musical reworkings of the Dolapdere Big Gang. This tendency is particularly evident within Turkish cinema of the 1970s, in which elements of American popular culture were being appropriated and utilised in a diverse range of cinematic contexts including 3 Dev Adam (dir. T. Fikret Ucak 1973), which transposes the characters Captain America, Santo and Spiderman to modern day Istanbul, and Turist Ömer Uzay Yolunda (dir. Hulki Saner 1974), which inserts the indigenous character Turist Ömer into a remake of the Star Trek episode 'The Man Trap.' This article will focus on Şeytan (dir. Metin Erksan 1974), an unofficial, unlicensed remake of The Exorcist (dir. William Friedkin 1973) with specific attention paid to the ways in which this remake replaces the prevailing Catholic iconography with that of Islam.

There have been some important developments in remake theory in recent years (Horton 1998; Mazdon 2000; Verevis 2006) that have attempted to move beyond reductive value judgements and stale conceptions of textual fidelity to analyse remakes through the 'material, historical and political conditions which surround and penetrate the moment of production and subsequent moment(s) of reception' (Mazdon 2000: 26). Building on this work, and utilising Tom O'Regan's model of cultural exchange and transmission, this article seeks to build a model of transcultural appropriation attendant to the underlying tensions and negotiations within this hybrid cultural text.

Initially, this interrogation of material conditions necessitates a discussion of the status of Turkey within contemporary political debates, critically examining the notion of Turkey as a country 'torn' between East and West. Second, the article outlines some of the key historical developments in Turkish popular cinema, paying especial attention to the phenomenon of Yeşilçam out of which Şeytan developed. Third, a close textual analysis of the film attends to the ways in which this remake transforms elements of The Exorcist and the contextual factors that shaped these changes. Finally, the article proposes a model of transcultural appropriation that locates these transformations within the wider socio-cultural climate in which they were enacted.

preposition meaning 'across, through') rather than 'inter' (from the Latin preposition meaning 'between, among') as I wish to indicate the fluidity and movement of 'across' in transcultural, as opposed to intercultural with its emphasis on 'between' cultures and the resultant sense of separateness. 


\section{Bridge of Civilisations}

Few, if any issues in international relations have generated as much myth as that of an alleged 'Islamic threat.' Since the late 1970s, and more particularly since the Iranian revolution of 197879 , the issue of 'Islam' and of its supposed challenge to the 'West' has become a matter of enduring international preoccupation, and one which politicians within Western European states, as well as a number of Islamic leaders, have chosen to highlight. (Halliday 1996: 107)

In 1993 Samuel P. Huntington famously predicted a 'clash of civilisations' between 'Islam' and 'the West' following the collapse of Marxist-Leninism and the end of the Cold War (1993: 22-28). According to this model of international affairs, the fall of the Berlin Wall signalled the end of the mutually supportive security ties between the USA and Muslim states, and a subsequent shift in power within many Muslim countries towards more anti-Western political parties. Without the common enemy of the Communist USSR, previous alliances would gradually fall away and international conflict would become less about ideology or economics and more about opposing cultures and civilisations.

As Edward Said later argued, such a model of transcultural relations is fundamentally reductive and incomplete. Huntington's thesis centres on the interactions of eight major civilisations, of which 'the West' and 'Islam' take up the structuring opposition. Such a model reduces the dynamics and plurality of these civilisations to essentialised blocs, which, as Said argues, paints the world, 'as if hugely complicated matters like identity and culture existed in a cartoonlike world where Popeye and Bluto bash each other mercilessly' (Said 2001). Significantly, when Huntington deals with Turkey's position in this global model, he attempts to undermine the prevalent model of Turkey as a cultural bridge, painting it instead as a 'torn' country:

Turkish leaders regularly described their country as a 'bridge' between cultures. Turkey, Prime Minister Tansu Ciller argued in 1993, is both a 'Western democracy' and 'part of the Middle East' and 'bridges two civilisations, physically and philosophically'...A bridge, however, is an artificial creation connecting two solid entities but is part of neither. When Turkey's leaders term their country a bridge, they euphemistically confirm that it is torn. (Huntington 1998: 149)

Huntington's model relies on a binary opposition being made between East and West, Asia and Europe, refusing to acknowledge the dynamic interdependency and heterogeneity of these cultural blocs. Stretching his thesis to fit a country that pointedly refuses to fit such a binary, Huntington falls back on empty rhetoric rather than addressing the fundamental difficulties such a model faces when discussing a nation 
such as Turkey.

Turkey is both Muslim and secular; a country that is both European and Asian. Indeed, Istanbul, the only metropolis in the world that straddles two continents, has at one time served as the capital city of the Roman Empire (330-395 CE), the Byzantine Empire (395-1204 and 1261-1453 CE), the Latin Empire (1204-1261 CE), and the Ottoman Empire (1453-1922 CE), its cityscape extending on both the European side (Thrace) and the Asian side (Anatolia) of the Bosphorus Strait. Designating Turkey as a 'torn country' presents the world in terms of monolithic blocks far removed from the dynamic interactions of culture that such a history indicates. ${ }^{2}$

When Mustafa Kemal Atatürk came to power and founded the Turkish Republic in 1923, he instituted westernising reforms aiming to break away from the Ottoman legacy and to orientate Turkey decidedly towards Europe (Chaudhuri 2005: 67). Inspired by the European republican model and the writings of Muslim secularist Ziya Gökalp, Atatürk brought in a number of key reforms designed to radically alter the shape and structure of the society. Symbolised in the six arrows of his party's emblem-populism, republicanism, nationalism, secularism, statism and reformism - these reforms included such symbolic changes as the banning of the fez in 1925, the introduction of a new code of law in 1926, and the replacement of the Ottoman script (based on Arabic with Persian influences) with the Latin alphabet in 1928.

Most controversial of all Atatürk's reforms were those related to secularism, including the abolishment of the caliphate - the supreme political office of Islam worldwide - the disestablishment of the state religion and the removal of all Islamic practices from public life. Underlying this was a sense of Turkish nationalism and a desire for Turkey to reject its Ottoman history and become a new 'nation-state'. As Nezih Erdoğan and Deniz Göktürk note,

\footnotetext{
${ }^{2}$ Indeed, it is worth noting that the Ottoman Empire was itself very much part of Europe and European history, as well as Asian/Middle Eastern history, in both a geographical sense (at its zenith, the Empire reached to the 'doors' of Vienna), and a more metaphorical sense (the values of 'Christian' Western Europe were partly constructed in opposition to their Ottoman 'other' in the East).
} 
After the founding of the Republic in 1923, a nationalist discourse that had already been gaining power in the final years of the Ottoman Empire was disseminated directly by the state, aiming to legitimise a transition from ummet (from umma, meaning the Islamic community or population) to millet (from mille, meaning nation). (Erdoğan \& Göktürk 2001: 534)

With the traditional association between state and religion having been dissolved, the nation-state became an instrument in what Nizayi Berkes calls 'the real aim of the Turkish transformation' (1997: 510): modernisation and economic development. Of course, we should not neglect that this embrace of secularism in the name of modernisation was itself heavily politically charged. As cultural anthropologist Yael Navaro-Yashin argues in Faces of the State: Secularism and Public Life in Turkey, "Secularism is not a neutral paradigm, but a state ideology as well as a hegemonic public discourse in contemporary Turkey" (2002: 6).

This nation-building involved a narcissistic idealisation of collectivity, what Robins and Aksoy term the 'deep nation,' which, they argue, gradually unravelled throughout the secularist/Islamist conflict in late twentieth century Turkey. For these authors the story of Turkish cinema, 'can be told in terms of the progressive disordering of the ideal of the Kemalist nation, which may be regarded as a productive disordering' (2000: 215). Indeed, the popular cinema of the period reflects this 'disordering of the Kemalist state,' with the predominant Yeşilçam mode of cinema often reflecting 'traditional, usually folk-Islamic, values' (209) far away from the Republican ideal of the nation.

Yeşilçam ${ }^{3}$ was the name given to the mode of popular film production that dominated the Turkish cinema sector between the 1960s and 1980s. Comparable to the term Hollywood, Yeşilçam (literally 'green pine') refers to both a physical locale where many of the film studios were located in Istanbul, and the style of popular filmmaking that was produced by these studios. Throughout this period, imported cultural forms and materials were often being reworked and adapted for the local audience, a practice that reflected an increasingly industrial mode of production within the Turkish film industry. In the context of these cultural shifts, I will now turn to the film Şeytan, a Turkish remake of the US horror feature The Exorcist, and a film produced at a time of rising Islamic consciousness.

\footnotetext{
${ }^{3}$ For a further discussion of Yeşilçam, see my forthcoming article, 'Beam me up, Omer: Transnational Media Flow and the Cultural Politics of the Turkish Star Trek Remake’ (2008).
} 


\section{Fantastik Türk Sineması}

Şeytan marked a collaboration between two of the key figures in Turkish cinema history: producer Hulki Saner and director Metin Erksan. Saner, one of the most successful and prolific filmmakers in Turkey, began the project after seeing that The Exorcist was courting media attention and inciting controversy around the world. At a time when censorship of US films was still commonplace-The Exorcist was not to be officially released in Turkey until 1982 - Saner decided to capitalise on this public interest by producing a Turkish version of the film for the domestic audience. Indeed, Saner, who had previously achieved success with both the Turist Ömer and Aysecik series, resolved to make this a prestige project, hiring acclaimed director Metin Erksan to helm the film and giving him a relatively large budget for a Yeşilçam production.

Erksan himself was already a celebrated filmmaker, one of the figureheads of the social realist movement in the 1960s, and winner of the Golden Bear at the 1964 Berlin Film Festival for the film Susuz Yaz (Dry Summer, 1964). While he is generally seen to have gradually abandoned the social outlook of his earlier works, moving towards a more 'popular' mode of film production, ${ }^{4}$ Erksan was a filmmaker of considerable weight and stature to bring to this Yeşilçam project.

While it would be easy to position this remake as an unoriginal copy of the prior film, this study will follow Lucy Mazdon's innovative work on remakes, looking less at questions of 'origins' and 'authenticity' and more towards a study of remakes that shows the remake to be a site of 'difference' rather than a site of the 'same'. As Mazdon argues,

Rather than a search for origins (the linear causality of the relationship between the 'original' and the 'copy') a study of this kind involves a description of exchange and difference; the unbroken vertical axis which leads from the 'original' text to the remake as 'copy' is replaced by the circles of intertextuality and hybridity. (Mazdon 2000: 27)

Furthermore, the prevailing critical mood to condemn remakes for their supposed lack of originality neglects the ways in which elements are appropriated and transformed within a particular socio-cultural context. As Tom O'Regan argues in his discussion of Australian National Cinema (1996), imitations and adaptations are commonly

\footnotetext{
${ }^{4}$ Erksan was later to helm an adaptation of Hamlet, Intikam Melegi - Kadin Hamlet (Angel of Vengeance, 1976), in which Hamlet is a woman, Ophelia is a man, and Rosencrantz and Guildenstern become two young women named Rezzan and Gul.
} 
dismissed as pale imitations of the 'original' works. To correct this deficiency, O'Regan proposes a model of appropriation that is focused less on the concept of imitation and more on the notion of transformation and negotiation. Centrally, this leads O'Regan to postulate that the distinctiveness of Austrialian national cinema may not rest in some notion of separate Australian-ness but, rather, 'may be found in its negotiation of cultural transfers' (219).

Within a Turkish context, Savas Arslan has recently introduced the term 'Turkification,' which relies on a similarly transformative notion of cultural exchange. Reclaiming the term from its use as derogatory slang, ${ }^{5}$ Arslan uses the term to describe the various practices of "translating, transforming or rendering Western cinemas" (96). Importantly, rather than seeing these transformations in terms of two discrete national cinemas coming into contact, Arslan lays emphasis on the fluidity of these cultural formations and their overlapping, intersecting nature:

Turkification is a translation of the West. However, this translation does not simply take place between two languages, but also through other elements of cultural multiplicities. It is not reducible to a transfer of one set to another, each clearly coded and therefore decidable. Here the West and the East are not totalities that are identifiable with a firm set of elements; instead they may be thought of as planes on which various particularities float. (Arslan 2006: 98)

This article, then, will analyse Şeytan through an interrogation of the ways in which the home culture restructures the imported text and by locating these negotiations within the specific socio-cultural climate in which they were enacted. Rather then searching for some essential 'Turkishness' or indeed 'Westernness' in the text, this will be an analysis of the ways in which these negotiations reflect the contextual conditions that shaped this particular transcultural appropriation.

\section{Şeytan}

The film, as in The Exorcist, opens on an archaeological expedition in the Middle East where an elderly man discovers various historical artifacts signifying the devil. We then cut to a domestic scene featuring Ayten (Meral Taygun) and her twelve year old daughter Gul (Canan Perver). During the subsequent scenes, the theme from The Exorcist (Mike Oldfield's 'Tubular Bells') is repeatedly used to set tone and suspense. ${ }^{6}$

\footnotetext{
${ }^{5}$ In Germany, the term getürkt ('turkified') has come to be used as a derogatory term meaning 'falsified' or 'corrupted,' and is associated with the large Turkish diaspora in the country.

${ }^{6}$ Such an act of unlicensed plagiarism of music from the source films was not uncommon.
} 
Up till this point, the film is a close recreation of the plot and characters of The Exorcist. Significantly, however, the introduction of Tugrul Bilge (Cihan Unal) represents an important moment of translation. Replacing the role of Father Karros from The Exorcist, Tugrul Bilge is a secular writer/journalist who is researching the ancient notion of demonic possession from the perspective of mental health. Indeed, the film offers a prolonged close-up of the cover of his book, Satan: The case of Demon Possession and the Rite of Exorcism in Universal Religions under the Light of Modern Perspectives on Mental Diseases, serving both to introduce the audience to the notion of exorcism, while avoiding the problem of having a central character who is questioning his faith in Allah.

Translative changes such as this have led some critics to condemn Şeytan as internally disjointed. ${ }^{7}$ By transforming The Exorcist into an Islamic context, the film attempts to compensate for the lack of an earthly presence of Satan in Islam by replacing it with the notion of Jinn and the spirit Iblis. These changes are evident in the exorcism scene itself:

Imam: Allah, I find shelter in your holy name. I praise your greatness. Your boundless power will end this torture made by the creature you created from the fires to the one you created from the clay...Banish this cruel Iblis from the soul of this innocent servant.

Such expository dialogue points to the emphasis the film lays on explaining the nature of exorcism to the audience, a concept not 'incompatible' but certainly unfamiliar in contemporary Turkish culture. Significantly, at the start of the narrative, neither Father Karros in The Exorcist nor Tugrul Bilge in Seytan believe in 'exorcisms' and they attempt to explain away their respective lead girl's troubles in terms of modern, scientific understandings of mental illness rather than seeing it in terms of 'possession' per se. This scepticism about religious dogma forms the core theme of both The Exorcist and Seytan, in that the various scientific methods for explaining the girl's illness, which include psychotherapy, shock therapy, and a lumbar puncture, fail to clarify what happened to Gul. The key revelation in each character's narrative trajectory is that scientific rationale cannot explain all that happens in the world and that we need to return to religion, a notion that has especial resonance in secular Kemalist Turkey.

\footnotetext{
${ }^{7}$ Indeed, Savas Arslan goes as far as to call the film 'incoherent' for this very reason.
} 
As we can see in Figures 1 and 2, the adaptation from Catholicism to Islam further necessitated a number of iconographic alterations. The moment from The Exorcist in which Regan defiles herself using the cross is adapted with the use of a Jinn shaped paper knife (Figure 1). While in the exorcism ceremony itself, instead of using Christian holy water, the Imam uses Zemzem water from the holy well of Zemzem, and reads from the Qu-ran rather than the Bible (Figure 2). Significantly, however, these are not simply cosmetic changes but subtly impact the development of the narrative. Most importantly, it is the ending of the film that exhibits the most significant alteration. Rather than ending with the death of Father Karros, as in The Exorcist, Seytan adds an extra scene in which Gul and her mother visit a Mosque. In these few moments, Gul spends some reflective time with an Imam while the camera pans the interiors of the mosque, reconfirming the renewal of Islam in these characters lives. Going beyond the bleak, harrowing ending suggested in The Exorcist, Şeytan offers a more redemptive conclusion laying emphasis on the religious overtones of the narrative.

Both The Exorcist and SSeytan deal with the perceived failings of scientific rationalism and propose the continued relevance of religion in the modern world. As William Friedkin states in his introduction to The Exorcist DVD,

The Exorcist is a film about the mystery of faith...It's a story that can perhaps make you question your own value system. It strongly and realistically tries to make the case for spiritual forces in the universe, both good and evil. (Warner Bros 1999)

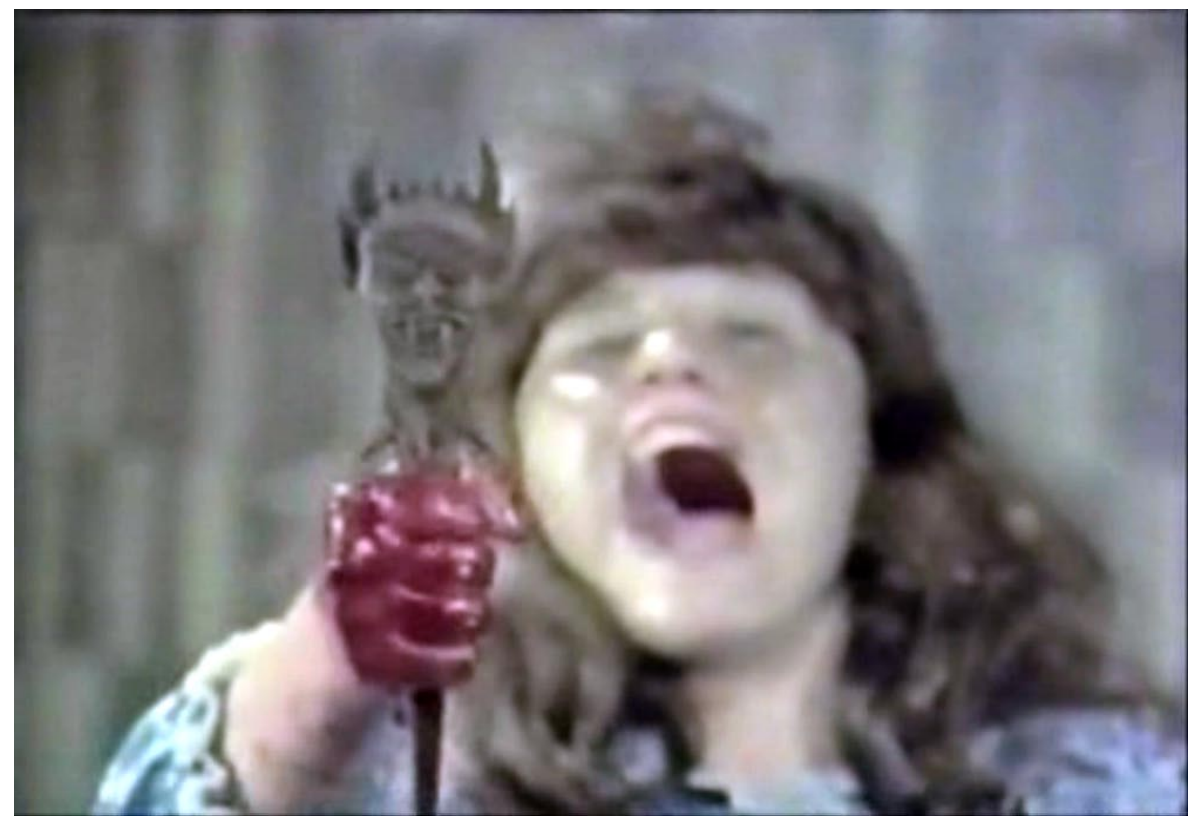

Figure 1: Şeytan (Metin Erksan, 1974) 


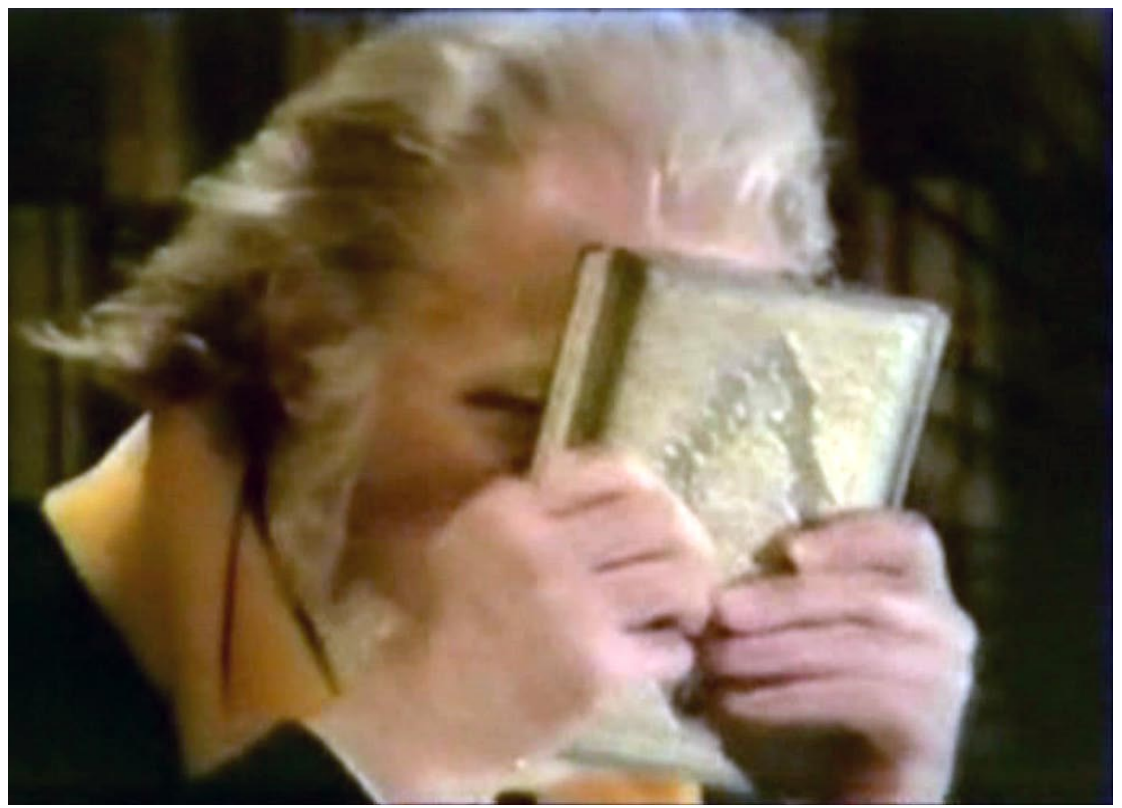

Figure 2: Şeytan (Metin Erksan, 1974)

This theme had added significance in post-Atatürk Turkey, with Şeytan produced at a time when the Kemalist embrace of Western conceptions of modernisation and rationalism was being questioned and Islam was again coming to the fore in Turkish political life. The reforms of Atatürk centred on taking Islam out of public life and moving Turkey towards a more European model of a rationalist, secular culture. To produce a film, then, which highlights the failings of this rationalist, secular discourse, and explicitly celebrates Islam for being able to defeat the 'evil' forces in the world, should be read as a partial repudiation of Atatürk's reforms and an attempt to reconfirm the importance and validity of Islam in the modern world. As Kaya Özkaracalar notes, 'this is by no means a cosmetic issue for Turkey, but on the contrary, one of the major causes of social unrest in this country' (2003: 214).

\section{Conclusion}

National audiences, critics and filmmakers appropriate, negotiate, and transform the international cinema in various ways... Any claims we may make about the space of - and distinctiveness of [national cinemas] must turn on the participation, negotiation, adaptation and hybridisation following on from unequal cultural transfers. (O’Regan 1996: 231)

As should be clear, then, Seytan is not an incoherent attempt to simply plagiarise a Western style horror film, but instead is an attempt to appropriate elements from a prior film in order to comment on, and reflect upon, issues that had significant resonance in the Turkish culture of the time. It is a 'Turkification' of The Exorcist that restructures 
the imported text in order to affirm the relevance of Islam in contemporary secular Turkey.

At a time when a clash of civilisations is being widely predicted, whether between Islam and Christianity or more broadly the East and the West, it is time to pay attention to the overlapping, intersecting nature of cultures and the hybrid, symbiotic relationship between them. Opposing the essentialist positions that envision cultures as 'pure' and under threat of being tainted by the 'other,' it is my intention that this model of transcultural exchange will draw attention to the intricate processes of borrowing and exchange through which cultures evolve, and go somewhat towards answering that call from Edward Said with which I opened.

\section{Reference List}

Akin, F. (dir.) 2005, Crossing the Bridge: The Sound of Istanbul, Corazón International.

Arslan, S. 2006, Hollywood Alla Turca: A History of Cinema in Turkey, Unpublished PhD thesis, Ohio State University.

Berkes, N. 1997, The Development of Secularism in Turkey. $2^{\text {nd }}$ Edition, Hurst, London.

Chaudhuri, S. 2005, Contemporary World Cinema; Europe, The Middle East, East Asia and South Asia. Edinburgh University Press, Edinburgh.

Erdoğan, N. and Göktürk, D. 2001, 'Turkish Cinema,' Companion Encyclopaedia of Middle Eastern and North African Film, ed. O. Leaman, Routledge, London, 533-73.

Erksan, M. (dir.) 1964, Susuz Yaz, Hitit. (dir.) 1974, Şeytan, Saner Film. (dir.) 1976, Intikam Melegi - Kadin Hamlet, Ugur Film.

Fikret Ucak, T, (dir.) 1973, 3 Dev Adam, Renkli.

Friedkin, W. (dir.) 1973, The Exorcist, Warner Brothers.

Gürata, A. 2006, 'Translating Modernity: Remakes in Turkish Cinema,' Asian Cinemas: A Reader and Guide, Eds. D. Eleftheoritis and G. Needham, Edinburgh University Press, Edinburgh, 242-54.

Halliday, F. 1996, Islam and the Myth of Confrontation. IB Taurus, London.

Horton, A. and McDougal S. 1998, Play it Again, Sam: Retakes on Remakes. University of California Press, Berkeley.

Huntington, S. 1993, 'Clash of Civilizations,' Foreign Affairs, vol. 72, no. 3, (Summer), 22-28. 1998, The Clash of Civilisations and the Remaking of World Order. Touchstone, London.

Kraidy, M. 2005, Hybridity, or the Cultural Logic of Globalization. Temple University Press, Philadelphia.

Lake, M. (ed.) 2005, The EU \& Turkey: A Glittering Prize or a Millstone? Federal Trust, London.

Lotman, Y. 1990, The Universe of the Mind: A Semiotic Theory of Culture. IB Tauris, London.

Mazdon, L. 2000, Encore Hollywood: Remaking French Cinema. BFI, London.

Navaro-Yashin, Y. 2002, Faces of the State: Secularism and Public Life in Turkey. Princeton University Press, Princeton.

O’Regan, T. 1996, Australian National Cinema. Routledge, London.

Özkaracalar, K. 2003, 'Between Appropriation and Innovation: Turkish Horror Cinema,' in Fear Without Frontiers: Horror Cinema Across the Globe, ed. S. Schneider, FAB Press, London, 204-17.

Pang, L. 2006, Cultural Control and Globalization in Asia: Copyright, Piracy and Cinema. Routledge, London.

Robins, K. And Aksoy, A. 2000, 'Deep Nation: The National Question and Turkish Cinema Culture' in Cinema and Nation, eds. M. Hjort and S. MacKenzie, Routledge, London, 203-21.

Said, E. 2003 (1978), Orientalism: Western Conceptions of the Orient. $25^{\text {th }}$ Anniversary Edition, Penguin, London. 
2001, 'The Clash of Ignorance,' The Nation, 22 Oct. Online. Available:

http://www.thenation.com/doc/20011022/said (Accessed 30 March 2007).

Saner, H. (dir.) 1974, Turist Ömer Uzay Yolunda, Saner Film.

Scognamillo G. and Demirhan, M. 1999, Fantastik Turk Sinemas, Kabalc Yaynevi, Istanbul.

Smith, I. 2008 (forthcoming), 'Beam Me Up, Omer: Transnational Media Flow and the Cultural Politics of the Turkish Star Trek Remake,' in Velvet Light Trap, 61 (Spring).

Simpson, C. 2006, ‘Turkish Cinema's Resurgence: The 'Deep Nation' Unravels,' Senses of Cinema, vol. 6, no. 39. Online. Available: http://www.sensesofcinema.com/contents/06/39/turkish_cinema.html (Accessed 30 March 2007).

Verevis, C. 2006, Film Remakes. Edinburgh University Press, Edinburgh.

Warner Brothers 1999. 'The Fear of God Documentary' on The Exorcist: $25^{\text {th }}$ Anniversary Edition, dir. W. Friedkin [DVD], Warner Brothers. 